\title{
SOME LESSONS FROM THE EAST ASIAN MIRACLE
}

\author{
Joseph E. Stiglitz
}

The rapid economic growth of eight East Asian economies, often called the "East Asian miracle," raises two questions: What policies and other factors contributed to that growth? And can other developing countries replicate those policies to stimulate equally rapid growth?

This article, based on case studies, econometric data, and economic theory, offers a list of the ingredients that contributed to that success. But it is the combination of these ingredients, many of which involve government interventions acting together, that accounts for East Asia's success.

he remarkable success of the economies of East Asia raises the question:
to what can that success be attributed? In most of the eight economies
that are part of the "East Asian miracle"-Hong Kong, Indonesia, Japan, the Republic of Korea, Malaysia, Singapore, Taiwan (China), and Thailand-government undertook major responsibility for the promotion of economic growth. Which policies contributed to the success of these economies, and why? Ascertaining what would have happened in the absence of the specified policy is often difficult. That the government subsidized a sector that grew rapidly does not imply that the growth should be attributed to the government's action. The sector might have grown without government intervention.

This article is an interpretive essay based on case studies, econometric data, and economic theory. In formulating a coherent explanation of East Asia's experience, I do not present a formula or a simple recipe, but rather a list of ingredients. Because these ingredients are interactive, and because they were introduced in conjunction with other policies, the government's approach has to be evaluated as a package. Indeed, East Asia's success was based on a combination of factors, particularly the high savings rate interacting with high levels of human capital accumulation, in a stable, market-oriented environment-but one with active government intervention-that was conducive to the transfer of technology.'

Each of the economies is unique; each differs in its history and culture. Some, such as Singapore and Hong Kong, are small city-states. Others are large. Many 
are racially and culturally homogeneous; some, such as Malaysia, are culturally diverse. But it seems implausible to attribute the success of each of these countries to special factors; the task instead is to discover the common threads.

Moreover, the unique factors typically refer to certain cultural aspects, such as a Confucian heritage, that are suspect: not that long ago, the Confucian heritage, with its emphasis on traditional values, was cited as an explanation for why these countries had not grown. To be sure, cultural factors may play an important role: the stress on education has contributed much to the success of these countries.

\section{Statistical Explanations}

Having expressed reservations about the usefulness of cultural explanations, it is important to note as well the limitations to the standard statistical techniques. For almost four decades (Solow 1957), the standard approach has been to ask to what extent this growth can be explained by increases in inputs, that is, human and physical capital, and expenditures for the acquisition of technology. In this approach, the "miracle" is the amount of this growth that cannot be so explained (the residual). Several such studies have argued that the East Asian experience can largely be explained by rapid increases in inputs-high levels of investment and heavy expenditures for education. Krugman (1994) and Young $(1993,1995)$ argue that essentially all of the growth in Singapore can be so explained. Others, such as Kim and Lau (1993) and World Bank (1993), find more evidence of a positive residual, but even then it is not unusually high. There are a variety of technical reasons why the applicability of this methodology to at least several of the East Asian countries should be suspect. Whatever their flaws, however, these studies still offer an important lesson: policies that increase the accumulation of physical and human capital are likely to lead to more rapid growth. The real problem is what these studies leave unanswered. The unique and changing circumstances of each country and the multitude of programs involved, each with a number of potentially important features, imply that a statistical study would be relevant only for addressing the broadest questions: were savings rates unusually high, or were financial restraints associated with faster rates of economic growth? Such studies do not identify those features that facilitated what in retrospect was a remarkable transformation of the economy. To understand this transformation, answers must be found to the following:

First, why were saving rates so high? Elsewhere, such saving rates had only been attained under the compulsion of strong government force, as in the Communist countries. Although studies suggest that these saving rates may be explained in part by economic factors-such as high growth rates that spurred high saving rates, as consumption lagged increases in incomes (Carroll, Weil, and Summers 1993; Stiglitz and Uy 1996)-government actions also played an 
important role in mobilizing savings (although this "virtuous cycle" between growth and savings was important as well).

Second, how was it possible to invest efficiently at such a rapid pace? To be sure, if life consisted of nothing more than adding homogeneous capital to a homogeneous production process, East Asia's success would hardly be remarkable. But in that case other countries that attempted to invest rapidly would have had far more success than they have had.

Third, how was it possible to reduce the technology gap so quickly? Clearly, more was entailed than just buying technology. To encourage the transfer of technology from foreign investors, the East Asian economies made enormous investments in human capital, educating large numbers of skilled engineers able to absorb and adapt the most advanced technology. And the East Asian economies were willing to accept foreign investment and create an economic atmosphere conducive to its entry. ${ }^{2}$ Moreover, they combined these efforts with an emphasis on the most technologically advanced investment.

And finally how did East Asia ensure that the benefits of rapid growth were spread widely among the population? Previous theories suggested that rapid growth was associated with rapid capital accumulation, which in turn was associated with high degrees of inequality; and that growth would in fact be accompanied by an increase in the degree of inequality (Kuznets 1955). Not only did this assumption prove to be false, but there are reasons to believe that government policies that promoted greater equality contributed in no small measure to the remarkable growth of these countries.

\section{Metaphors of Economic Growth}

Several metaphors are used to describe the process of economic growth. These metaphors undoubtedly influence how we think about the subject.

\section{An Engine Metaphor}

Perhaps the most popular metaphor is that which refers to the engine of growth-as if there were a motor driving the performance of the economy. Capital accumulation is often given credit for being the engine of growth. And the countries of East Asia certainly have accumulated capital at an impressive rate. Sometimes the concept of capital accumulation is broadened to include human capital-the improvement in the skills of the labor force. And sometimes these two are given credit not only for their direct contribution, but also for the technical progress that might not have occurred in their absence.

Once one identifies the engine of growth, one tries to make the engine stronger. Thus, if capital accumulation is the engine, the task is to increase capital accumulation. The role of government is to rev up the engine to encourage a higher rate of capital accumulation. The engine metaphor has some important 
limitations: it encourages a search for particular factors that account for growth, although it may in fact be the system as a whole, including the interactions among the parts, that accounts for growth. If human capital accumulation is inadequate, even rapid physical capital accumulation may be ineffective. But if both are required, which one is the engine?

\section{A Chemical Metaphor}

I prefer two other metaphors for thinking about the growth process. One is borrowed from chemistry: the government as catalyst. The government can be a catalyst for growth without necessarily providing a great deal of resources. Indeed, that is the remarkable property of catalysts-having set off a chemical reaction, they are themselves not used up in the process. At the very least this metaphor warns that the effect of some government policy should not be measured simply by asking about the magnitude of the subsidy or what fraction of the funds was provided by the government. More concretely, investments in human capital and infrastructure, both physical and institutional, can increase the private return to investment and thereby promote growth.

\section{A Biological Metaphor}

The second metaphor, "adaptive systems," is borrowed from biological terminology. Species that survive adapt to changes in their surroundings. More advanced species survive in part because of their ability to learn. Thus the most important characteristic for survival is not a particular policy, but the ability to respond to changes in the environment and to learn from past mistakes. Adaptability is often said to distinguish private sector enterprises from government bureaucracy. But government, because of its monopoly powers, can survive even if it does not adapt well or quickly. The East Asian economies demonstrated that government too can be highly adaptive. When changes in the environment made previously adopted policies inappropriate, these governments changed course, and they learned quickly from their mistakes. As their economies grew and became more complex, the state's role clearly had to change: there was neither the need nor the capacity for active intervention on the scale previously assumed. And officials recognized the importance of adopting policies to promote higher levels of technology and higher value-added industries.

\section{A Metaphor from Physics}

One metaphor has been omitted from this list-the one that has in fact dominated the economics profession for almost a century-the economy as an equilibrium system. The omission is deliberate: it is a metaphor that provides little insight into the dramatic changes that occurred in these societies. The equilibrium metaphor suggests that individuals had (perhaps rational) expectations 
concerning future rates of return; given those expectations, they determined their saving rate; meanwhile, profit-maximizing firms scoured the world looking for the best products and technologies to employ, given the costs of adjustment. In this metaphor, too, government played at most an ancillary role. This metaphor leaves unasked-and unanswered-such fundamental questions as, What set the East Asian countries apart from other countries? Why is their experience so different?

\section{Complementing Markets Rather Than Replacing Them}

Before the East Asia miracle there were two dominant paradigms for development, one focused on markets, the other on government and planning. The first had its intellectual roots in Adam Smith's "invisible hand": markets lead to efficient outcomes. All that government needs to do to promote growth is get out of the way. The basic slogan is "get the prices right." With the right prices, everyone will have an incentive to make the right resource allocations. Undermining this particular religion was the disturbing observation that countries that seemed to get the prices right-to follow all the advice of the visiting preachers of the free market-too often failed to grow. To be sure, like medieval medicine, there was always the allegation that the patient had not followed the doctor's orders precisely, and it was this that accounted for the failure of the remedy.

At the opposite side were those who had little faith in the market and who looked to government to ensure through the planning process that resources were deployed in a way that promoted economic growth. The lack of success of those countries that followed this paradigm has led to the virtual extinction of this school of thought.

Ironically, almost none of the successful industrial countries followed either of these extreme strategies. They are mixed economies in which government plays an important role. The appropriate question to be asked is not whether government should play a role, but what role and how can it be performed most effectively.

At the same time that the success of the East Asian economies and the collapse of the socialist economies called into question the standard paradigm, advances in economic theory called into question the intellectual foundations of these two approaches. In the mid-1950s Arrow and Debreu (1954) identified several conditions that must be satisfied if markets are to yield efficient outcomes. These include, first, the absence of externalities (external economies or diseconomies that affect the activity in question) and of public goods (commodities or services that, once provided, can be obtained without payment by others); second, the presence of perfect competition; and, third, a complete set of markets, including markets extending infinitely far into the future and covering all risks. A market failure is said to occur where these conditions are not satisfied. This approach identified specific interventions by the government to 
correct each market failure, for instance, pollution taxes to correct for environmental damage. Government had a well-defined, highly circumscribed role.

It was not until thirty years later, however, that the full limits of the market mechanism became well understood. Hidden in Arrow and Debreu's framework were strong assumptions about information and technology. In their model information need not be perfect, but it could not change as a result of actions taken within the economy. Greenwald and Stiglitz (1986) showed that whenever information was imperfect or markets were incomplete, government could devise interventions that filled in for these imperfections and that could make everyone better off. Because information was never perfect and markets never complete, these results completely undermined the standard theoretical basis for relying on the market mechanism. Similarly the standard models ignored changes in technology; for a variety of reasons markets may underinvest in research and development (see, for example, Stiglitz 1987, 1988, and Arrow 1962). Because developing economies have underdeveloped (missing) markets and imperfect information and because the development process is associated with acquiring new technology (new information), these reservations about the adequacy of market mechanisms may be particularly relevant to developing countries (Stiglitz 1989).

The modern theory of market failures recognizes, however, that government interventions may not actually improve matters. Theories of regulatory capture and rent-seeking imply that government interventions may contribute to inefficient resource allocation, and whatever their weaknesses, these theories have sufficient plausibility to suggest that governments need to exercise caution. How the government intervenes may matter a great deal.

The fundamental mistake of the countries of the former Soviet Union and those developing countries that tried to rely on planning was that they sought to correct market failures by replacing the market. The governments of East Asia, by contrast, recognized the limitations of markets but confined the government's role to

- Policies that actively sought to ensure macroeconomic stability.

- Making markets work more effectively by, for instance, regulating financial markets.

- Creating markets where they did not exist.

- Helping to direct investment to ensure that resources were deployed in ways that would enhance economic growth and stability.

- Creating an atmosphere conducive to private investment and ensured political stability.

In short, rather than replacing markets, these governments promoted and used them. Such interventions had to be carefully balanced; if they were too heavy-handed, they might have squelched the market. This agenda required government to design interventions in a way that reduced the likelihood of rentseeking behavior and that increased its ability to adapt to changing circum- 
stances. One such mechanism was a performance-based reward structure that provided strong growth-oriented incentives and served as a basis for awarding government subsidies. This structure was relatively free from corruption and helped to direct resources to areas that produced high economic returns. Another essential step was to design a civil service system based on merit, which compensated employees well and built in provisions that reduced the dangers of corruption.

In this discussion, the interventions are organized around four major themes: industrial policies, cooperation and competition, equality, and export-led growth. Some of the most important actions to promote economic growth were directed to the financial market, and these interventions are the subject of the accompanying article in this journal by Stiglitz and Uy.

\section{Industrial Policies}

Industrial policies are directed at developing and encouraging certain sectors. What were these industrial policies? Why were they adopted? And did they work, either by directing resources to desired areas or, more broadly, in promoting economic growth?

\section{What Policies Were Pursued?}

Most countries shared three objectives: developing technological capabilities; promoting exports; and building the domestic capacity to manufacture a range of intermediate goods (such as plastics and steel). Support for particular industries and imports of the necessary foreign technology took several forms. First, the support for education-particularly engineering and science education-provided an intellectual infrastructure that facilitated technological transfer. Second, the decision to discourage (through financial market regulations) the allocation of capital to areas such as real estate meant that more capital was available for areas with higher technological benefits, such as plants and equipment. Third, as discussed later, the government encouraged exports. Fourth, in some industries, particularly those with many firms, government promoted technology programs, including science centers that offered services ranging from identifying new products to providing research and development for firms that had no facilities of their own. Taiwan (China) and Malaysia developed industrial parks for high-technology industries, both to allow firms to capture some of the diffuse externalities associated with these industries as well as to lower the barriers to entry. (Diffuse externalities arise when the actions of one firm benefit-or confer costs upon-many firms, rather than, say, just one upstream firm or one downstream firm.) And finally, the government provided explicit and implicit subsidies (through cheap credit) to industries it wished to support. 
An important element in the expansion of certain industries was a receptivity to direct foreign investment. The East Asian economies not only resisted xenophobic aversions to foreign investments, but they also induced capital inflows by providing sound macroeconomic management, a stable political environment, and well-managed labor markets with educated workers. In many cases governments took explicit steps to ensure that a transfer of technological and human capital would accompany these inflows. Foreign investment increased the pace of expansion, reducing the constraints imposed by limitations on the availability of capital, domestic entrepreneurship, and technological know-how.

\section{Why Were Industrial Policies Adopted?}

Market failures are likely to be particularly significant in developing countries for several reasons. ${ }^{3}$ Understanding these market failures helps explain the policies that were adopted and the reasons they were so effective.

WEAK AND NONEXISTENT MARKETS. In the early stages of development, markets often do not exist or work well, so prices may not provide good signals for resource allocation. In East Asia capital markets were particularly weak, leading government to create institutions to promote savings (the postal savings banks) and to extend long-term credit (the development banks). Governments also tried to develop the financial infrastructure by helping to establish bond and equity markets (Stiglitz and Uy 1996).

Having promoted savings, governments had to decide how to allocate these funds. If there had been well-established market institutions for allocating longterm capital, governments could have made use of those institutions. But because the governments had to decide how to allocate resources, it was natural to direct the funds to projects that would yield the highest level of social welfare.

TeChNological sPILlovers. Private markets have inadequate incentives for investing in the production and acquisition of technology, largely because it is difficult to appropriate the returns to knowledge. Developing countries typically operate at a level of technology far below that of industrial countries; development is, to a large extent, the process of acquiring and adapting existing technologies. Patent protection ensures that the seller can command some payment for new technology, but it does not provide much protection for a firm that transfers and adapts an existing technology. Adopting and adapting new technologies involves a risk. If successes are quickly imitated, then firms face a "heads I lose, tails you win" situation: when they succeed, there is little profit because of the force of competition; when they fail, they lose money.

MARKETING SPILLOVERS. Still another kind of valuable information concerns marketing. Knowing where there is a market for a product is not information that can be kept secret. If a firm spends money to discover that Americans like 
madras shirts, then any manufacturer of madras shirts can take advantage of that information. The converse is that the products of a country establish a reputation. Thus, Japan's reputation for high quality benefits all Japanese producers.

Such marketing spillovers have led governments to adopt programs aimed at promoting the country's products. (In Hong Kong these programs are financed by a special tax. In Singapore they are directed by the powerful Economic Development Board.) Spillovers have also resulted in an array of programs to improve the countries' reputation. Most notable in this respect is the recent effort by Taiwan (China) to encourage its domestic firms to obtain brand recognition.

RETURNS TO SCALE: a problematic explanation. Not all of the arguments advanced as rationales for industrial policies are persuasive, however. One that seemed particularly influential in Japan held that government intervention was required to rationalize industry. It was argued that without government support, firms would be too small, and the large number of such firms would reduce the profitability of all firms in a sector. (Thus, the Japanese government not only condoned the increased concentration in the steel industry in the late 1960 s but, in one of its most famous mistakes, tried to discourage Honda-at the time a successful manufacturer of motorcycles-from entering the automobile market.) This argument is unpersuasive because if there truly were increasing returns to scale, then a single firm would benefit by increasing its production; in time its costs would be lowered, and it would then be able to undercut its rivals. Natural economic forces lead to the rationalization of industries without government intervention.

A slight variant of the argument about returns to scale does have some validity. Increasing returns combined with a shortage of capital may stunt small firms. They cannot expand to take advantage of increasing returns either because they cannot get access to capital or because the only form of capital to which they have access is credit, which imposes too high a risk. In this case, government intervention can lower the costs of capital and increase economic efficiency.

Increasing returns, especially when combined with capital market imperfections, provide the foundation for strategic trade policy. Historically, arguments for government trade interventions focused on industries with learning by doing. If today's production lowers future marginal costs, that creates a form of increasing returns akin to the more familiar static increasing returns. A firm that expands production lowers its future production costs and undercuts its rivals. The infant industry argument holds that protection is important so that the young firm can gain the experience required to lower its production costs and allow it to become viable. Critics of this argument claim that if the firm is to be profitable in the long run, it should incur any necessary losses today. But this assumption is based on the premise that capital markets are perfect. With imperfect capital markets, a firm may not be able to sustain the losses that would enable it to produce at a level at which it would eventually become profitable. 
Moreover, if the firm is unable to appropriate all the returns to its learning, then social returns to production will exceed private returns (Dasgupta and Stiglitz 1988). In addition, dominant firms in industrial countries are likely to take advantage of the lack of competition that prevails when learning is important by raising prices and increasing their profits. Government policies may be directed at trying to appropriate some of these rents (the excess profits that result from a dominant competitive position).

COORDINATION FAILURES. The widespread absence of markets in developing countries means that prices cannot perform their coordination role. Government may thus have to assume a more active role in performing this function. The traditional examples relate to the development of downstream and upstream industries: developing a steel-manufacturing industry does not pay unless there is a steel-using industry; and developing a steel-using industry does not pay if there is no steel-manufacturing industry. If both wait, nothing happens. According to this view, the government has an important function in coordinating the two activities. Such coordination failures, it is argued, are likely to be most important when the returns to scale are large. For instance, if manufacturing steel is deemed to be desirable, it is necessary to build a large steel plant and a large steel-using industry. Other market failures, such as the absence of risk markets, interact with this failure: large risks are likely to accompany such largescale investments, and the market provides no mechanism by which these risks can be divested. Moreover, no single entrepreneur could amass the capital required, and the imperfections of the capital market mean that it cannot supply the funds required. Developing countries are less likely than industrial countries to have the organizations capable of undertaking these large investments in a single sector, let alone the capacity to undertake the investments in both the upstream and downstream firms. Thus coordination problems may be larger in developing countries, and the capacity to deal with them may be smaller.

The earlier arguments for coordination failures (Rosenstein-Rodan 1943 and Murphy, Shleifer, and Vishny 1989) were rightly criticized as unpersuasive (Stiglitz 1994a). Such a problem could easily be addressed through trade-one of the solutions devised by the East Asian countries (without benefit of the theoretical literature). It is possible to develop a steel-using industry simply by importing steel and to develop steel producers without steel users simply by exporting steel.

In the early stages of rapid growth, the subsectors responsible for the takeoff in many, if not most, of the East Asian countries-textiles, footwear, sporting goods, toys-were not those in which economies of scale or coordination problems seemed important. But there was a more subtle form of returns to scale in which government intervention did matter and which affected growth even in these areas: the availability of a wide range of intermediate-often fairly complex-goods, tailored for the producers of final goods. The sellers of these intermediate goods do not capture all of the benefits that their greater availability 
provides. The improved two-way flow of information between the producer and the user, which permits better coordination in the development of the intermediate and final goods, is a benefit of proximity. That explains why importing the intermediate good does not serve as a perfect substitute for domestic production and also provides a rationale for government intervention. In Malaysia it is claimed that the local auto manufacturer has provided important spillovers to the intermediate goods firms that produce parts and that these firms, in turn, have benefited producers of other final goods.

STRATEGIC NEGOTIATIONS. In negotiations with other countries or companies, the governments of East Asia have often recognized-and taken advantage ofthe nature of the market environment. The outcome of any bargaining depends on the strength of competition on both sides. By reducing competition among buyers of technology and trying to increase competition among sellers, the governments succeeded in appropriating more of the surplus associated with the transfer of technology than otherwise could have been captured. In Japan, for instance, a single firm was sometimes given the right to negotiate a licensing agreement; it might then be compelled to share the technology with other firms in the industry.

\section{Did These Policies Work?}

Industrial policies have been widely criticized, on the (somewhat contradictory) grounds that they were ineffective or distortionary. The first criticism suggests that industrial policies are more form than substance. Critics cite statistics such as the small percentage of loans made by the development banks. These statistics are unconvincing, however: the consequences of, say, a loan by the Industrial Bank of Japan may be far greater than the actual dollars lent, because of either its signaling or risk-sharing effect (Stiglitz and Uy 1996). Government policies that increase the equity of a firm can have immense effects through the power of leveraging. Beyond that, there was a wide range of instruments for effecting industrial policies; it is the cumulative effect of all of these that matters. The criticism is more properly directed at those who have suggested that Japan's Ministry of International Trade and Industry totally controlled the allocation of resources. This assumption is wrong on two counts. First, firms made most of the decisions about resource allocation-influenced, to be sure, by government policies, but not directly controlled by them. None of the East Asian countries is a command-and-control economy. Second, the view that government makes decisions on its own seems misguided. Consultation between business and government was extensive (and many of the top leaders of business were former government employees).

The charge that industrial policy was distortionary, however, is of more concern. Even if there is a rationale for government intervention, this view alleges that government does not do a good job at picking winners. Instances of mis- 
takes by the government are typically cited. In some cases the government discouraged a firm (Honda, for example), when in retrospect it clearly should not have; and in others the government encouraged some industry (such as petrochemicals), when in retrospect it probably should not have.

There are four responses to this criticism. First, good decisionmaking by the government necessarily involves making mistakes: a policy that supported only sure winners would have taken no risks. The relatively few mistakes speak well for the government's ability to pick winners. Second, the government was not heavy-handed. Although it made mistakes of judgment, it did not force its opinions on others when they were willing to risk their own capital. This is one of the strengths of decentralized decisionmaking: it ensures that mistaken views will not dominate.

Third, to a large extent, government policies were not directed at picking winners in the narrow sense of the term. Several governments decided to support export-oriented industries. In a sense, that was choosing a winning development strategy; it did not necessarily entail micromanaging. Even when the government identified an industry for support, the banks seem to have had discretion to select which firms or projects within that industry to support.

Fourth, industrial policies were focused not so much on picking winners as on identifying market failures-instances where investors could not capture large potential spillovers. Concern about such spillovers helps explain the government's encouragement of high technology industries. Training provides another example. Firms would benefit from a trained labor force, but, because workers can leave for a better job once they are trained, firms have inadequate incentives to proceed with training. Yet a skilled work force is essential for economic growth, so government undertook to improve the quality of the labor force by emphasizing education.

Moreover, the criticism of industrial policies as misguided attempts to pick winners ignores the broader range of government actions, such as its role in spearheading the expansion of certain manufacturing sectors. "Picking winners" seems to imply culling from a fixed pool of applicants to find those with the highest long-run social returns. East Asian governments have instead performed an entrepreneurial role. Entrepreneurship requires combining technological and marketing knowledge, a vision of the future, a willingness to take risks, and an ability to raise capital. In early stages of development, these ingredients are typically in short supply. The governments in East Asia stepped in to fill the gap-but in a way that promoted rather than thwarted the development of private entrepreneurship.

Government was also effective in monitoring the recipients of its support and ensuring that they did not siphon off funds for private use. Other government policies, such as those that led to more equity financing, reduced the magnitude of the monitoring problem; that is, they resulted in firms having more appropriate incentives. Still other policies, such as those that enhanced the stability of the banking system, led to more effective monitoring by financial institutions. 


\section{Cooperation and Competition}

Popular discussions of the success of Japan and several other East Asian countries have stressed the cooperative relations between government and business, between workers and employers, and between small and large businesses. Clearly, the extent of this cooperation (sometimes referred to as "Japan Inc."), has been exaggerated. Yet a variety of institutions and practices facilitate cooperation, and this kind of cooperation appears to have had beneficial effects. Adam Smith's "invisible hand" of perfect competition argues that because each individual, in pursuing his self-interest, is also maximizing the common welfare, cooperation is not necessary. But when market failures occur, it is not necessarily the case that the selfish pursuit of self-interest leads to efficient outcomes.

The governments of East Asia recognized that the business community had superior information about investment decisions, but they also recognized that the overall information base could be improved. The establishment of formal and informal councils gave rival firms and industries a way to exchange information with each other and with the government. (This information exchange process is sometimes described as akin to indicative planning, but the analogy is, at best, an imperfect one.) These exchanges conveyed far more information than the traditional format used to display planned sectoral inputs and outputs. What made them more meaningful than such exchanges in other countries? Why would businesses, or government for that matter, tell the truth?

To a large extent, good behavior is induced through long-term relationships and reputations. In the process of development, social sanctions become less effective in enforcing cooperative behavior, but establishing and maintaining alternative bases for cooperative relations may be difficult. The gains from cooperation are based on the perception that the future returns to cooperation exceed the short-run gains that might accrue from the pursuit of self-interest. But an environment of rapid change may heighten uncertainty about the value of the future relationship and the magnitude of the long-term gains from cooperation. Moreover, future cooperative gains have to be discounted (meaning that, because they may not materialize in the future, they are worth less in today's terms). Typically uncertainty is greater and discount rates higher in developing countries. Further, concerns about the potential bankruptcy of one or the other firm, which could terminate the relationship, heighten the likelihood that cooperative relationships will not materialize. Under these circumstances, future gains from cooperation must be greater to compensate firms for sacrificing the shortrun gains from self-interested behavior.

\section{Encouraging Cooperation}

The Japanese government used both carrots and sticks to encourage cooperation and the exchange of truthful information. Although cultural characteristics are often credited with facilitating this harmonious result, other countries with 
similar cultural backgrounds have not displayed the same sort of cooperative behavior seen in Japan. It seems far more likely that government actions were more important than culture in shaping these behavioral patterns.

Of the institutions and mechanisms that facilitated cooperation, an important role was played by business councils set up to share reliable and timely information. Why did not some businesses try to "free ride," to obtain the information provided by others while providing no real information themselves? The answer is, in part, that they were in a longer-term relationship; a firm that "cheated" would be ostracized from the circle. The fact that the government was included in these circles was important: firms wanted to know what the government was thinking about specific projects or what policy changes were planned. Even if a firm's cooperative instincts went astray, self-interest was a strong incentive. Moreover, by paying attention to these councils, the government ensured that the gains from cooperation were even greater.

The government's discretionary powers enabled it to reward cooperation and honesty, and there was at least a fear that the lack of cooperation and the appearance of dishonesty would be punished. Government intervention in markets created rents that the government could then allocate to participants who behaved cooperatively. For example, by restricting the formation of branch banks, a large franchise value was associated with the right to have a branch. Similarly, restricting credit meant that access to credit had value. And the Bank of Japan (the central bank) could, on a discretionary basis, provide banks with additional funds when needed.

The relative stability of the East Asian governments increased the incentives for establishing long-term cooperative relations. At the same time, long-term relations enhanced the effectiveness of incentives (Stiglitz and Weiss 1983). Firms that performed well on one project could expect to be rewarded with another project.

The East Asian governments also tried to create an environment conducive to close cooperation among businesses. In Japan, for instance, the government tried to encourage mergers. To the extent that these programs were successful (and there is considerable controversy about that), they reduced the difficulties of cooperation. The smaller the group, the easier cooperation is to attain. Here the government was walking a fine line; a small group could-and may-have led to collusion by restricting competition. In some circumstances, the government approved the formation of so-called recession cartels. These cartels were an explicit attempt to deal cooperatively (and collusively) with the problems that arise in a recession when there is excess capacity in a capital-intensive industry. Under certain conditions, as demand shifts down, prices drop and firms are unable to recover their capital costs. Recession cartels were a way to restrict competition to enable the industry in question to avoid the low prices that would damage all the firms. Whether the gains were worth the costs of reduced competition, higher prices, and underutilized resources is not clear, however. Because of the strong incentives to cheat on such arrangements, cartels are seldom suc- 
cessful without legal sanctions from the government. In some cases the Japanese government paid firms to destroy equipment, and in others, to seal equipment shut. Even these tactics were not always successful; some firms did not completely dismantle their equipment.

Labor markets were similarly designed to encourage cooperative behavior. The Japanese pattern of lifetime employment was important because it meant that employees had long-term relationships with employers, which facilitated cooperative behavior. The rapid increase in wages that came with age and experience provided a strong incentive for workers to stay with their organizations. The average pay of each age cohort increased sharply, but differentiation within the age cohort remained smaller than in, say, the United States. Japan's prevalent compensation scheme, in which a large part of the salary was paid as an annual bonus (based largely on profits of the previous year), also encouraged cooperation because workers had, in effect, an equity stake in the firm. This form of risk-sharing may be particularly important in early stages of development when capital markets are underdeveloped. Because wages are based on the group's performance, the individual has an incentive to monitor his peers to make sure that his co-workers are working hard (Arnott and Stiglitz 1991; Stiglitz 1990b). One might even go further. Basing salary on individual performance encourages self-interested, noncooperative behavior. Conversely, paying wages based on group performance signals the importance of cooperative behavior.

Also important in Japan's labor market was the government-established Productivity Council, which dealt with the degree of inequality that could exist within a firm and limited salaries of top managers to no more than ten times the wages of the lowest-paid workers. ${ }^{4}$ This compressed wage structure enhanced the sense that top management was not taking advantage of workers and led to greater effort and lower labor turnover.

Cooperative behavior between firms and their employees is particularly important in facilitating technological change. Workers are often in the best position to identify improvements in efficiency, although such improvements do not always redound to the benefit of the workers. Because labor-saving innovations may result in less demand for labor and higher unemployment, employees are often reluctant to disclose such ideas. If, however, the firm provides a guarantee of lifetime employment, existing employees will see no conflict between their interests and those of the firm. Moreover, when wages are based partially on firm profitability, interests coincide: if the productivity-enhancing innovation enhances profits in the long run, employees will share in the gain. Of course, when growth is rapid firms can more easily promise that labor-saving innovations will not result in reduced employment, which makes it more credible that all (existing) employees will benefit from such innovations.

Cooperative behavior between firms and their banks was also evident in the operations of capital markets. In Japan each firm had a long-standing relationship with a single bank, and that bank played a large role in the affairs of the firm. Japanese banks, unlike American banks, are allowed to own shares in the 
firms to which they lend, and when their client firms are in trouble, they step in. (The fact that the bank owns shares in the firm means that there is a greater coincidence of interest than there would be if the bank were simply a creditor; see Stiglitz 1985.) This pattern of active involvement between lenders and borrowers is seen in other countries of East Asia and was actively encouraged by governments.

Another important aspect of business-government cooperation in Japan has been the attempt to reduce bankruptcies, which have been markedly less cyclical than those in the United States and other countries. This pattern reflects not only the country's better macroeconomic performance and a legal structure that encourages actions short of bankruptcy but also an active government policy directed at avoiding the economic disruption caused by bankruptcy.

\section{Combining Competition and Cooperation}

The East Asian countries succeeded (not always, but with a remarkable frequency) in harnessing the advantages of cooperation while retaining the advantages of competition. Cooperation to increase efficiency can easily be turned into collusion to raise prices and restrict output and entry. Worse still, discretionary powers needed for cooperation can give rise to rent-seeking and corruption. Competition both enhanced efficiency and reduced the scope for abuses of discretionary powers. In fostering a competitive industrial structure, governments looked not so much at the number of firms in an industry, but at the effectiveness of the competition; competition may be more effective with two evenly matched firms than with one firm competing.with many small rivals (Nalebuff and Stiglitz 1983).

By the same token, the process of identifying which workers to promote in Japanese firms may be more effective in encouraging competition than is the process in the United States. In Japan, where workers are less mobile, a cohort of workers hired together advances together. They all work hard; they all have to signal that they are committed to the firm; they all remain in the contest. In the United States decisions concerning who is on an upward career ladder often take place earlier. Under that system, incentives may be strong in the early stages of individual careers, but they may be greatly attenuated once these decisions are made. Those who know that they are not going to be "winners" have little reason to work hard.

One method introduced to stimulate competition was the use of contests. Governments rewarded firms that performed well relative to others (such as in exports) by, for example, providing them with access to capital and foreign exchange. In many instances, the value of the prize arose from the government intervention: if the government had not created artificial scarcity of capital or foreign exchange, an increase in availability would have had no incentive effect. 
Well-functioning contests are characterized by rules that establish a clear criterion for rewards, such as export performance; specify the nature of the reward (the allocation of credit or foreign exchange); and indicate who will evaluate performance. This system reduced the scope for abuse of bureaucratic discretion at the same time that it provided strong incentives.

Ironically, licensing requirements put in place to restrict competition may give rise to more competitive behavior. At various times, the Japanese government imposed restrictions on the expansion of capacity in certain industries. It awarded licenses to expand capacity on the basis of firms' previous market shares. Thus performance-particularly growth-in one year may increase profits not only in that year, but also in subsequent years.

\section{Growth with Equality}

Although industrial policies attempt to direct resource allocations in ways that maximize growth, income distribution policies seek to promote greater equality. Historically, the development process has been characterized by marked increases in inequality (the Kuznets curve). It was alleged that the massive amounts of capital accumulation required could only be attained through significant inequality; the poor simply could not save enough. Moreover, growth creates winners (the owners of those firms that do well), and losers (workers displaced from lagging industries, in particular agriculture). The economies of East Asia were able to achieve rapid growth without an increase in inequality. Indeed, active policies promoting equality probably enhanced growth (figure 1).

In Korea, Japan, and Taiwan (China), land reforms-at least partially imposed from the outside-were important in the initial stages of development. These had three effects: they increased rural productivity and income and resulted in increased savings; higher incomes provided the domestic demand that was important in these economies before export markets expanded; and the redistribution of income contributed to political stability, an important factor in creating a good environment for domestic and foreign investment.

In later years policies to ensure more equitable distribution of income continued to contribute to economic growth, with positive effects that more than offset the possible negative effects of reduced capital accumulation upon which earlier discussions had focused. These policies continued to contribute to political stability. High and increasing wages reduced inequality, made workers not only more satisfied but also (by standard efficiency wage arguments) more productive, and promoted cooperative relations between workers and firms. Policies that attempted to restrict rẹal estate speculation (by limiting lending for that purpose) can be viewed both as part of industrial policy and as part of income distribution policy. While they directed funds into industry, they limited the increases in the prices of housing relative to what would otherwise have occurred. Such price increases would have led to demands for further wage in- 
Figure 1. Income Inequality and Growth of Gross Domestic Product, 1970-93

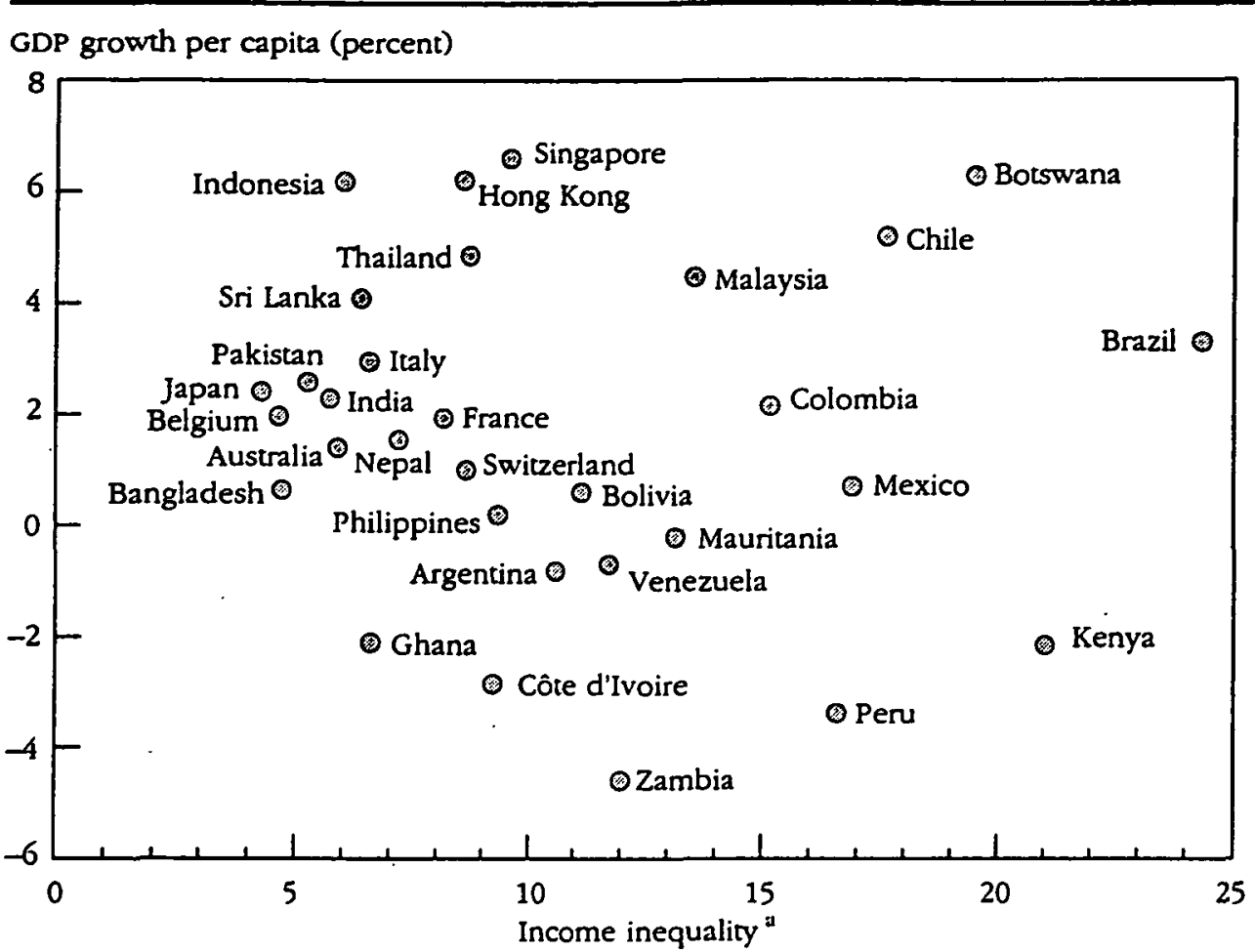

a. Income inequality is measured by the ratio of the income shares of the richest 20 percent and the poorest 20 percent of the population.

Source: World Bank data.

creases and would have had particularly adverse effects on the very poor, who often seem unable to obtain adequate housing under such conditions.

Additionally, policies ensuring universal literacy both increased productivity and promoted greater equality. The emphasis on female education led to reduced fertility, thus mitigating the adverse effects of population pressure felt in so many developing countries, and it directly increased the supply of educated labor. Most studies suggest that a worker's wage performance is more directly related to nonschool factors, such as home background, than to education in school. Education of women can be thought of as a roundabout but high-return way of enhancing labor force productivity.

In Thailand a program to provide credit to the rural sector, although largely motivated by concerns about communist insurgency, seemed not only to have promoted equality but also to have yielded reasonably high economic returns. And in Malaysia, policies that would be regarded as affirmative action elsewhere were able not only to draw upon a reservoir of human talent that had not 
been well used before, but to weld together a nation that had already demonstrated a potential for ethnic strife.

There are positive relations between growth and equality. High rates of growth provided resources that could be used to promote equality, just as the high degree of equality helped sustain the high rates of growth. Although this may seem to be little more than common sense, until the experience of East Asia, "common sense" suggested quite the contrary: growth produced inequality, and inequality was necessary for growth.

\section{Export-Oriented Growth}

Why focus on exports? Should not countries simply produce the goods in which they have a comparative advantage, whether that happens to be products that are exported or substitutes for goods that are currently imported?s Success in exporting provided policymakers with an objective way to award credit and foreign exchange. ${ }^{6}$ Two questions arise: why are exports a better measure of performance than profits? And second, do markets reward success in an appropriate way without government intervention?

In measuring performance to determine which firms to favor with credit and other scarce resources, governments faced an information problem. All governments face a similar problem, but in the context of development, the information problem is particularly severe for two reasons. First, relatively few firms may be engaged in similar activities, so bases of comparison are limited. Second, a host of problems must be overcome-new supplier relationships, new markets, and so on. In such circumstances, short-run profits may be imperfect indicators of long-term performance. Consider, for instance, the two sources of profits: those derived from exports, and those derived from domestic sales. The latter may reflect either the firm's efficiency or its monopoly position in the economy. The profits that result from imperfect competition in the domestic market accrue at least partially at the expense of consumers and should not be thought of as a social gain. By contrast, a firm that succeeds in the export market is more likely to be economically efficient. It can market a product at a lower price than can foreign rivals, or one better tailored for the world market. Export markets are more likely to be competitive. And even if they are not, it is of no concern: the profits of the firm are then at the expense of foreign consumers. Indeed, from the exporting country's perspective, finding a niche within which some market power can be exercised is to be rewarded, not condemned.

Other advantages are also associated with exports. Firms learn a great deal in international markets, benefiting from spillovers related to both marketing and production know-how. For instance, success in producing intermediate goods requires producing to standards that are typically higher than those that prevail within developing countries. This generates a demand for testing laboratories. 
The recognition that standards are important and the knowledge about producing goods of higher quality has implications across a broad range of products. Moreover, the contacts established through exporting may be of value when the firm decides to enter related markets. It will, for instance, know where to turn to acquire advanced technology.

From a social perspective, success in exporting may be a better indicator of whether a firm merits additional funds than success in selling domestically, but banks have typically preferred lending to firms engaged in the domestic market, and for a simple reason. Banks do not care whether a firm makes social returns or private returns, as long as it can repay the loan. Banks are less informed about foreign markets and thus consider it riskier to lend for export projects than for the domestic market.

It has been argued that the preferences East Asian governments gave to exports were intended simply to offset the disadvantages of tariffs and other restrictions on imports. From this perspective, government was not promoting exports but simply "getting the prices right." Upon closer examination (even without a detailed scrutiny of the statistics), this argument appears faulty on two grounds. First, it refers to averages of exports; but what is relevant is the effective subsidy on particular exports. If some exports are encouraged and others (perhaps unintentionally) discouraged, it is apparent that government has intervened in the allocation of resources. Second, the government actually engaged in a wide range of activities beyond direct subsidies to promote exports.

\section{Export Promotion Activities}

Four activities were very important in promoting export growth: the provision of infrastructure; preferential access to capital and foreign exchange; the development of export markets; and licensing and other regulations designed to enhance the reputation of the country's exports. As noted previously, the close, long-term relationships between exporters and governments can be credited with making these mechanisms work.

THE PROVISION OF INFRASTRUCTURE. Because poor infrastructure is an important barrier to trade, East Asian governments have invested in infrastructure, including good port facilities and improved transportation systems to reduce the costs of shipping goods abroad. Transportation is not the only aspect of infrastructure that has received government attention. Singapore has been involved in efforts to provide an adequate supply of electricity and an effective telecommunications system, both vital to the country's development as a financial center.

PREFERENTIAL ACCESS to CAPITAL AND FOREIGN EXCHANGE. Most of the countries of East Asia engaged in some degree of financial restraint, that is, capital markets were controlled to give priority industries preferential access to capital and foreign exchange (Stiglitz and Uy 1996). Although in some cases govern- 
ments provided subsidies (including lower interest rates) to encourage the expansion of favored industries, most observers believe that the access to credit was far more important.

Critics of this access raise the issue of fungibility: what if the government did provide credit and funds for investment in export-oriented industries? So long as money is fungible, large conglomerates could simply divert to other uses those funds that would have been allocated to exports. Consequently, financing exports may have little incremental effect on exports. From this perspective, the allocation of capital to the export sector has no marginal effect. It has only an inframarginal effect on firms that are successful in exporting. This view, however, does not take account of the process by which funds are allocated. If past export performance is used as one of the criteria for judging the creditworthiness of the borrower, firms have an incentive to increase exports. And firms that were successful exporters had demonstrated some set of abilities. If those abilities were correlated with other abilities that enhanced the likelihood of high marginal returns to investment, then the use of export performance may have been an efficient selection mechanism.

DEVELOPING NEW EXPORT MARKETS. Information problems associated with the development of new export markets go beyond the problems of reputation. One noted earlier was the "public good" nature of information. As in the case of other public goods, a strong case can be made for public provision. And many of the East Asian economies have done just that. For instance, Singapore's Economic Development Board has actively worked on developing foreign markets and takes an active interest in what goods might be produced for export. Business executives are invited to join official trips abroad to persuade them that it is in their interests to enter into meaningful business relationships overseas.

ENHANCING THE REPUTATION OF THE COUNTRY'S EXPORTS. In the 1950s and early 1960 s, Japanese products had a reputation for being shoddy. American and European buyers had little information about individual Japanese producers and were likely to make unfavorable inferences concerning any particular product. Because establishing a reputation is expensive for any firm seeking to export (particularly when consumers have strong negative prior beliefs), individual firms had little incentive to improve the quality of their products. The government conducted a concerted effort both to improve the quality of the products and to establish brand reputations for Japanese firms, so that they would have private incentives to maintain their reputation. Here is an example of an interaction between cooperative behavior and individual incentives. A similar process is occurring in Taiwan (China), where the government is effectively providing subsidies for firms to establish brand recognition. In doing so, firms will have a private incentive to maintain high quality, with positive effects on the reputation of Taiwanese products in general. 


\section{Conclusion}

One of the reasons for attempting to delineate what East Asian governments did that resulted in such high growth rates is that other countries would like to replicate their success. If they did the same thing as the governments of East Asia, would they too grow at such rapid rates? To be sure, many countries did similar things, but often with adverse rather than positive effects. They created development banks, only to find that the development banks diverted scarce savings into projects with low returns and made investments that did more to line the pockets of politicians than to raise the welfare of the country. The East Asian miracle had many dimensions: rents were created, but they were used to encourage growth, not dissipated in rent-seeking. Government and businesses cooperated closely, but they collaborated without collusion. Many aspects of this transformation can be explained, and to the extent that they can be explained, it is possible that what they did can be replicated. A high rate of saving leads to high growth; allocating resources on the basis of contests and other performance-based measures can both provide high-powered incentives and reduce the scope for corruption; egalitarian policies, including active education policies, can contribute to a more stable political and economic environment and lead to faster growth through a more productive labor force. Governments that use markets and help create markets are likely to be more successful in promoting growth than governments that try to replace markets.

What generalizations can be drawn from the findings of this article? To be sure, not all of these generalizations are held with the same degree of confidence. In some cases, there are alternative interpretations of the events and evidence. But a combination of theory and evidence supports these conclusions. Included in the discussion below are several interventions in the financial market, which, although mentioned only briefly, are amplified in the accompanying article by Stiglitz and $U y$ in this issue. Because governments in different countries pursued somewhat different policies, not all the statements hold with equal validity in all countries; some may not even hold within all sectors of a given country. These conclusions are organized around six themes.

- Making society function better. Economic growth required the maintenance of macroeconomic and political stability. Policies that sustained a more equitable distribution of income-and that supported basic education for women as well as men-contributed to economic progress by encouraging political stability and cooperative behavior within the private sector. The result was a better business climate for investment and more effective use of human resources.

- Adaptability of government policies. Government policies adapted to changing economic circumstances, rather than remaining fixed. As the East Asian economies grew more complex, government had less need to assume an active role and found it more difficult to act effectively on a broad scale. 
- Government and markets. Governments played an active role in creating market institutions, such as long-term development banks and capital markets to trade bonds and equities, and in establishing an institutional infrastructure that enabled markets to work more effectively. These institutions and markets helped ensure that the high volume of savings was invested efficiently. Governments also used their control of financial markets to help direct resources in ways that stimulated economic growth. This control was probably more important than direct subsidies or low interest rates. Credit was directed not only toward priority areas, but away from speculative real estate and consumer durables.

Policies to improve government-business cooperation enabled governments to design programs that served the needs of the business community, created a favorable business climate, and encouraged business to direct its energies in ways that contributed to high social returns. Sharing information enhanced the quality of decisionmaking.

By using, directing, and supplementing markets rather than replacing them, the private sector remained the center of economic activity in most of the East Asian countries; when the private sector disagreed with the government, it was permitted to go ahead and risk its own capital.

- Promoting accumulation of physical and human capital. The introduction of postal savings institutions and provident funds resulted in higher domestic savings. At the same time, measures that established prudential regulations (and in some cases; entry restrictions) enhanced the safety and soundness of financial institutions and promoted financial deepening. A variety of programs increased the returns to private investment and facilitated the development and transfer of technology; these included policies that promoted education and training, provided infrastructure, and, in most countries, established a receptivity to foreign investment.

- Altering the allocation of resources. Governments in East Asia used industrial policies to affect the allocation of resources in ways that would stimulate economic growth. They took an entrepreneurial role in identifying industries in which research and development would have high payoffs. Support for industry, such as the establishment of research and science centers and quality control standards, was important both in attracting foreign investment and in encouraging domestic investors. Emphasizing industries with strong backward and forward links and large externalities may have helped long-term growth. In the short term, the lack of profitability does not provide a good measure of the potential long-run contribution to growth, precisely because it is the discrepancy between private and social returns that motivates government intervention.

Governments actively encouraged firms to export. Exports provided a performance-based criterion for allocating credit, encouraged the adoption of international standards, and accelerated the diffusion of technology. Contests among exporters were used widely as incentive devices. The essential 
ingredients of contests are rewards (here the allocation of credit), rules (measures of performance), and referees (who evaluate performance). In a world short of perfect competition, contests can provide strong incentives with limited risks, and, if the rules are well specified, reduce bureaucratic abuses.

- Government policies supporting investment. Mild financial repression had a positive effect on economic growth. The effects on national savings and on the efficiency with which scarce capital was allocated were likely positive; positive incentive effects may have been associated with the contest for scarce credit, and the increased equity of firms and banks (because of lower interest rates) enhanced their ability to bear risks. Equally important were other government programs that led to more effective risk-sharing within the economy. Risk-sharing reduced the effective cost of capital, thus stimulating investment. Government intervention in international economic relations (for instance, in bargaining for foreign technology, in impeding certain capital movements, and in insisting on certain transfers of technology as part of foreign investment) may have enhanced the national interest, promoted economic stability, and enhanced savings.

No single policy ensured success, nor did the absence of any single ingredient ensure failure. There was a nexus of policies, varying from country to country, sharing the common themes that we have emphasized: governments intervened actively in the market, but used, complemented, regulated, and indeed created markets, rather than supplanted them. Governments created an environment in which markets could thrive. Governments promoted exports, education, and technology; encouraged cooperation between government and industry and between firms and their workers; and at the same time encouraged competition.

The real miracle of East Asia may be political more than economic: why did governments undertake these policies? Why did politicians or bureaucrats not subvert them for their own self-interest? Even here, the East Asian experience has many lessons, particularly the use of incentives and organizational design within the public sector to enhance efficiency and to reduce the likelihood of corruption. The recognition of institutional and individual fallibility gave rise to a flexibility and responsiveness that, in the end, must lie at the root of sustained success.

\section{Notes}

Joseph E. Stiglitz is chairman of President Clinton's Council of Economic Advisers, on leave from Stanford University, where he is professor of economics. This is a shortened version of a paper written as part of the World Bank project on The East Asian Miracle and Public Policy. Financial and technical support of the World Bank is gratefully acknowledged. The author is particularly indebted to Marilou Uy. He has also benefited from discussions with Nancy Birdsall, John Page, Richard Sabot, Howard Pack, Edward Campos, Masahiro Okuno, Masahiko Aoki, Daniel Okimoto, Lawrence Lau, Professor Gato, Professor Baba, and dozens of other government officials, academics, bankers, and 
industrialists who gave generously of their time during this research project. Research assistance from Thomas Hellman is also gratefully acknowledged.

1. In the literature on this subject, particular reference should be made to the work of Alam (1989), Aoki (1988), Wade (1990), Amsden (1989), Okimoto (1989), Lau (1990), Agrawal and others (1992), Johnson (1982), Pack and Westphal (1986), Itoh and others (1984), Komiya, Okuna, and Suzumura (1988), and Vogel (1991), as well as to the country studies of the World Bank. The information theoretic foundation of the analyses presented here is set forth in greater detail in Greenwald and Stiglitz (1986, 1988, 1992), Arnott, Greenwald, and Stiglitz (1993), and Stiglitz (1994b). The implications for government policy are discussed in greater length in Stiglitz (1990a, 1991a, 1991b).

2. The contrast between India and Singapore could not bring this point home more clearly: India, with a population 300 times that of Singapore and a gross domestic product ten times as large, has a cumulative foreign investment one-fifteenth that of Singapore's.

3. The discussion of this section focuses on standard market failures associated with externalities, missing markets, and competition. The Greenwald-Stiglitz theorems, which go beyond these standard market failures, establish that whenever information is incomplete, a discrepancy may exist between social and private returns. An important application of this principle arises in the context of capital markets: the ratio of the private return to the supplier of capital to the social return may differ markedly (even in the absence of the traditional market failures). For instance, private lenders may be able to appropriate a larger fraction of the total returns to real estate lending than to other lending. For a fuller discussion of the implications, see Stiglitz and Uy (1996).

4. This should be contrasted with the United States, where, for instance, in recent years top executives often received 100 times the pay of recent hires. Within rapidly growing areas of China, the degree of inequality is even lower, with managers getring paid approximately three times the amount received by workers.

5. Note that several of the countries went through an import substitution phase, during which they were very successful. It is questioned whether this phase was necessary, whether it helped (or hindered) the growth process, or whether it was primarily a consequence of the particular economic doctrines that were fashionable at the time.

6. The arguments here are not those provided by government officials at the time (or even subsequently). These focused on more immediate concerns: for instance, in the postwar era, with an overvalued foreign exchange rate, Japan was short of foreign exchange. To some extent, it saw export activities as offsetting the disadvantages exporters faced as a result of the overvalued exchange rate.

\section{References}

The word "processed" describes informally reproduced works that may not be commonly available through library systems.

Agrawal, P., S. Gokarn, V. Mishra, K. Parikh, and K. Sen. 1992. "Learning from Tigers and Cubs." Discussion paper. Indira Gandhi Institute of Development Research. Bombay. Processed.

Alam, M. S. 1989. Governments and Markets in Economic Development Strategies. New York: Praeger Publishing.

Amsden, Alice H. 1989. Asia's Next Giant. New York: Oxford University Press.

Aoki, Masahiko. 1988. Information, Incentives, and Bargaining in the Japanese Economy. Cambridge, U.K.: Cambridge University Press.

Arnott, Richard, Bruce Greenwald, and Joseph E. Stiglitz. 1993. "Information and Economic Efficiency." NBER Working Paper 4533. National Bureau of Economic Research, Cambridge, Mass. Processed.

Arnott, Richard, and Joseph E. Stiglitz. 1991. "Moral Hazard and Non-Market Institutions: Dysfunctional Crowding Out or Peer Monitoring." American Economic Review 81(March):179-90. 
Arrow, Kenneth. 1962. "Economic Welfare and the Allocation of Resources for Invention." In National Bureau of Economic Research, The Rate and Direction of Inventive Activity: Economic and Social Factors. Princeton, N.J.: Princeton University Press.

Arrow, Kenneth, and Gerard Debreu. 1954. "Existence of Equilibrium for a Competitive Economy." Econometrica 22:265-90.

Carroll, Chris, David N. Weil, and Lawrence H. Summers. 1993. "Savings and Growth: A Reinterpretation." Paper presented at the Carnegie-Rochester Public Policy Conference, Bradley Policy Research Center, Rochester, N.Y. April 23-24. Processed.

Dasgupta, Partha, and Joseph E. Stiglitz. 1988. “Learning by Doing, Market Structure and Industrial and Trade Policies." Oxford Economic Papers 40:246-68.

Greenwald, Bruce, and Joseph E. Stiglitz. 1986. "Externalities in Economies with Imperfect Information and Incomplete Markets." Quarterly Journal of Economics 101(May):229-64.

- 1988. "Pareto Inefficiency of Market Economies: Search and Efficiency Wage Models." American Economic Review 78(2):351-55.

- 1992. "Information, Finance, and Markets: The Architecture of Allocative Mechanisms." Journal of Industrial and Corporate Change 1(1):37-63.

Itoh, Motoshige, Kazuharo Kiyono, Masahiro Okuno-Fujiwara, and Kotaro Suzumura. 1984. "Economic Analysis of Industrial Policy." Kikan Gendai Keizai (Contemporary Economy). Tokyo.

Johnson, Chalmers H. 1982. MITI and the Japanese Miracle. Palo Alto, Calif.: Stanford University Press.

Kim, Jung, and Lawrence J. Lau. 1993. "The Sources of Economic Growth of the East Asian Industrialized Countries." Paper presented at a Conference on the Economic Development of Republic of China and the Pacific Rim in 1990 and Beyond, Stanford University, Calif. Processed.

Komiya, Ryuraro, Masahiro Okuno, and Kotaro Suzumura, eds. 1988. Industrial Policy of Japan. San Diego: Academic Press.

Krugman, Paul. 1994. "The Myth of Asia's Miracle." Foreign Affairs 73(November/December):62-78.

Kuznets, Simon. 1955. "Economic Growth and Income Inequality." American Economic Review 45(1):1-28.

Lau, Lawrence J. 1990. Models of Development: A Comparative Study of Economic Growth in South Korea and Taiwan. San Francisco: Institute for Contemporary Studies Press.

Murphy, K. M., A. Shleifer, and R. W. Vishny. 1989. “Industrialization and the Big Push." Journal of Political Economy 97(5):1003-26.

Nalebuff, Barry, and Joseph E. Stiglitz. 1983. "Prizes and Incentives: Towards a General Theory of Compensation and Competition." Bell Journal 14(1):21-43.

Okimoto, Daniel. 1989. Between MITI and the Market. Palo Alto, Calif.: Stanford University Press.

Pack, Howard, and L. E. Westphal. 1986. "Industrial Strategy and Technological Change." Journal of Development Economics 22:87-128.

Rosenstein-Rodan, P. N. 1943. "Problems of Industrialization in Eastern and South Eastern Europe." Economic Journal 53(June-September):202-11.

Solow, Robert M. 1957. "Technical Change and the Aggregate Production Function." Review of Economics and Statistics 39 (August):312-20.

Stiglitz, Joseph E. 1974. "Theories of Discrimination and Economic Policy." In George M. von Furstenberg and others, eds., Patterns of Racial Discrimination. Lexington, Mass.: D.C. Heath.

1985. "Credit Markets and Control of Capital." Journal of Money, Banking and Credit 17(1):133-52. 
1987. "On the Microeconomics of Technical Progress." In Jorge M. Katz, ed., Technology Generation in Latin American Manufacturing Industries. New York: Macmillan Press.

1988. "Technological Change, Sunk Costs, and Competition." In Martin Neil Baily and Clifford Winston, eds., Brookings Papers on Economic Activity, 3 (special issue on Microeconomics):883-947. Washington, D.C.: Brookings Institution.

- 1989. "Markets, Market Failures, and Development." American Economic Review 79(2):197-203.

- 1990a. "On the Economic Role of the State." In A. Heertje, ed., The Economic Role of the State. Oxford, U.K.: Basil Blackwell and Bank Insinger de Beaufort NV.

. 1990b. "Peer Monitoring and Credit Markets." World Bank Economic Review 4(3):351-66.

. 1991a. "The Invisible Hand and Modern Welfare Economics." In D. Vines and A. Stevenson, eds., Information, Strategy and Public Policy. Oxford, U.K.: Basil Blackwell. 1991b. "Social Absorption Capability and Innovation." Paper prepared for Korean Development Institure 20th Anniversary Symposium, Seoul. June. Processed.

1994a. "The Role of the State in Financial Markets." In Michael Bruno and Boris Pleskovic, eds., Proceedings of the World Bank Annual Conference on Development Economics 1993. Washington, D.C.: World Bank.

- 1994b. Whither Socialism? Cambridge, Mass: MIT Press.

Stiglitz, Joseph E., and Marilou Uy. 1996. "Financial Markers, Public Policy, and the East Asian Miracle." World Bank Research Observer 11(2):249-76.

Stiglitz, Joseph E., and Andrew Weiss. 1983. "Incentive Effects of Termination: Applications to the Credit and Labor Markets." American Economic Review 73(December):91227.

Vogel, Ezra F. 1991. The Four Little Dragons: The Spread of Industrialization in East Asia. Cambridge, Mass.: Harvard University Press.

Wade, Robert. 1990. Governing the Market: Economic Theory and the Role of the Government in East Asian Industrialization. Princeton, N.J.: Princeton University Press.

World Bank. 1993. The East Asian Miracle: Economic Growth and Public Policy. New York: Oxford University Press.

Young, Alwyn. 1993. "Lessons from the East Asian NICs: A Contrarian View." NBER Working Paper 4482. National Bureau of Economic Research, Cambridge, Mass. Processed.

1995. "Growth without Scale Effects." NBER Research Working Paper 4211. National Bureau of Economic Research, Cambridge, Mass. Processed. 
Copyright of World Bank Research Observer is the property of Oxford University Press / USA and its content may not be copied or emailed to multiple sites or posted to a listserv without the copyright holder's express written permission. However, users may print, download, or email articles for individual use. 